\title{
Z DOŚWIADCZEŃ W DZIEDZINIE POPULARYZACJI BIBLII I WIEDZY BIBLIJNEJ
}

„Wiosna biblijna”, usankcjonowana przez II Sobór Watykański (1962-1965), podjęta i rozwijana w Kościołach lokalnych, zaowocowała bezprecedensowym zintensyfikowaniem studiów nad Biblią oraz ożywieniem popularyzacji Biblii i wiedzy biblijnej. Na jej kanwie - aczkolwiek początki decyzji i prac przygotowawczych sięgają znacznie wcześniej, bo jeszcze okresu przedwojennego ${ }^{1}$ - ukazała się Biblia Tysiąclecia, której drugie wydanie, zaaprobowane jako tekst liturgiczny, stało się Biblią katolików polskich i mówiących po polsku. Wznawiana (i poprawiana) w kolejnych latach trafiła do ogromnej, aczkolwiek trudnej do dokładnego oszacowania, liczby polskich domów, przyczyniając się wydatnie do zainteresowania słowem Bożym i czytania go oraz poszukiwania pomocy w celu jego właściwego zrozumienia i interpretacji.

W nurt posoborowego ruchu biblijnego wpisała się również działalność naukowa i popularyzatorska biblistów polskich. Jej składnik i egzemplifikację stanowią konferencje biblijne wygłaszane przez niżej podpisanego, zapoczątkowane w 1986 r. w sąsiadujących ze sobą warszawskiej parafii Opatrzności Bożej i parafii Zwiastowania Pańskiego na Rakowcu, a także w prowadzonej przez jezuitów parafii św. Andrzeja Boboli. Wielka w tym zasługa proboszczów - ks. prałata Romualda Kołakowskiego i ks. prałata Witolda Karpowicza, a także o. Mirosława Paciuszkiewicza SJ, redaktora „Przeglądu Powszechnego" i proboszcza parafii św. Andrzeja Boboli, którzy

1 Zob. W. C h ro s t o w s k i, U początków tradycji Sympozjów Biblistów Polskich, w: M.S. W ró b e 1 (red.), Deus meus et omnia. Księga pamiątkowa ku czci o. prof. Hugolina Langkammera OFM w 50. rocznicę święceń kapłańskich, Wydawnictwo Katolickiego Uniwersytetu Lubelskiego, Lublin 2005, s. 59-78. 
z wielką przychylnością odnieśli się do projektu oraz życzliwie i skutecznie go wspierali. W pierwszym okresie konferencje odbywały się co dwa tygodnie, poczynając od początku października do maja lub czerwca następnego roku. W późniejszych latach, zważywszy na liczne prace i zaangażowania prowadzącego, odbywały się w cyklu miesięcznym. Początkowo uczestniczyło w nich kilkadziesiąt osób, jednak ich liczba stale rosła i od początku lat 90. utrzymuje się na poziomie około pół tysiąca osób. Uczestnicy to w zdecydowanej większości świeccy - młodzi, dorośli i starsi, kobiety i mężczyźni, lecz także osoby duchowne - siostry zakonne i kilku kapłanów. Rekrutują się oni spośród miejscowych wiernych, mieszkających w warszawskiej dzielnicy Ochota, oraz z całej Warszawy i miejscowości podwarszawskich.

Przez kilkanaście lat każda konferencja była nagrywana, a następnie spisywana $\mathrm{z}$ taśmy magnetofonowej przez p. Bożenę Godycką, adiustowana, ponownie przepisywana na maszynie i kopiowana w setkach egzemplarzy oraz wręczana wszystkim słuchaczom na kolejnym spotkaniu. Dzięki temu istniała możliwość ponownego zapoznania się z ich treścią, przemyślenia i stawiania pytań oraz gromadzenia materiałów w spójną całość. Czas i okoliczności pozwoliły, by definitywnie opracować i wydać drukiem tylko jeden cyk1, poświęcony wybitnym postaciom pierwszej części Biblii chrześcijańskiej. ${ }^{2}$ Kiedy w latach 90 . komputery zastąpiły maszyny do pisania, opracowywanie poszczególnych konferencji stało się znacznie łatwiejsze. Z kolei z początkiem pierwszej dekady XXI w., gdy upowszechniło się używanie Internetu, dwaj uczestnicy konferencji, inżynier Józef Zwierko i doc. Jerzy Paczyński, włożyli mnóstwo pomysłowości i wysiłku, by nagrania wygłoszonych konferencji stały się dostępne w Internecie, co niezwykle powiększyło krąg ich odbiorców i zasięg oddziaływania. Na kanwie konferencji rozwinęło się też duszpasterstwo pielgrzymkowe. Bardzo wielu, zapewne większość uczestników spotkań odbywanych przez ponad ćwierć wieku,

2 Te n że, Bohaterowie wiary Starego Testamentu, Akademia Teologii Katolickiej, Warszawa 1992. 
pielgrzymowała do Ziemi Świętej i innych krajów biblijnych, dając wyraz swoim zainteresowaniom i wykorzystując nabytą wiedzę.

W niniejszym artykule wyszczególnia się tytułową problematykę dorocznych konferencji oraz szczegółowe tematy, podejmowane i rozwijane podczas poszczególnych spotkań. Wykaz ${ }^{3}$ jest pomyślany jako syntetyczna dokumentacja wieloletniego przedsięwzięcia oraz pomoc do planowania i urzeczywistniania podobnych inicjatyw w dziele popularyzowania Biblii i wiedzy biblijnej.

\section{Wykaz konferencji biblijnych za lata 1986-2015}

\section{Rok 1: 1986/1987}

\section{Parafia Opatrzności Bożej: Wprowadzenie do Ewangelii}

1. Miejsce Ewangelii w kanonie Nowego Testamentu.

2. Ewangelia według św. Mateusza (I).

3. Ewangelia według św. Mateusza (II).

4. Ewangelia według św. Marka (I).

5. Ewangelia według św. Marka (II).

6. Ewangelia według św. Łukasza (I).

7. Ewangelia według św. Łukasza (II).

8. Ewangelia według św. Jana (I).

9. Ewangelia według św. Jana (II).

10. Obraz Jezusa Chrystusa na podstawie czterech Ewangelii kanonicznych.

11. Jezus historii a Chrystus wiary.

12. „Idźcie i nauczajcie wszystkie narody” (Mt 28,19) - misyjny dynamizm Ewangelii.

3 Wykaz nie uwzględnia setek innych konferencji, prelekcji i wystąpień w tych samych miejscach, głównie o charakterze okolicznościowym, przede wszystkim wygłoszonych w kontekście ważnych wydarzeń za pontyfikatu Jana Pawła II i Benedykta XVI oraz Wielkiego Jubileuszu Roku 2000, ani wygłoszonych w dziesiątkach innych miejsc, w kraju i zagranicą; pełny wykaz tej działalności zob. w: B. S t $r$ z a ł k o w s k a, Ksiadz Profesor Waldemar Chrostowski. Laureat Nagrody Ratzingera (2014), Stowarzyszenie Biblistów Polskich, Warszawa 2014, s. 510-598. 
Parafia Zwiastowania Pańskiego: Wprowadzenie do Pisma Świętego

1. Kanon Starego i Nowego Testamentu.

2. Pismo Święte jako słowo Boże i słowo ludzkie.

3. Historia zbawienia Starego Testamentu.

4. Mesjański dynamizm Starego Testamentu.

5. Jezus Chrystus jako zasada jedności Biblii.

6. Ewangelie jako cztery portrety Jezusa Chrystusa.

7. Dzieje Apostolskie - świadectwo początków i okrzepnięcia Kościoła.

\section{Parafia św. Andrzeja Boboli: U początków Kościoła}

1. Wielopostaciowość judaizmu w I w. w świetle pism Józefa Flawiusza.

2. Wielopostaciowość judaizm w I w. w świetle pism Nowego Testamentu.

3. Obraz Jezusa w Nowym Testamencie i świadectwach pozabiblijnych.

4. Zesłanie Ducha Świętego i narodziny Kościoła (Dz 2).

5. Początki Kościoła w Jerozolimie.

6. Apostołowie Piotr i Jan przed Sanhedrynem.

7. Ananiasz i Safira (Dz 5,1-11).

8. Apostołowie przed Sanhedrynem.

9. Szczepan - pierwszy męczennik chrześcijański.

10. Przyjęcie pogan do Kościoła (Dz 10).

\section{Rok 2: Styczeń - czerwiec $1988^{4}$}

Parafia Opatrzności Bożej: Księga Rodzaju 1-11

1. Okoliczności, czas powstania i charakter literacki biblijnej „Historii początków”.

4 Konferencje biblijne odbywały się tylko w pierwszym półroczu 1988 r. z racji na intensywne w drugim półroczu 1987 r., w kraju i za granicą, zaangażowanie prowadzącego w dialog Kościoła z Żydami i judaizmem. 
2. Literacka kompozycja „Historii początków”.

3. Pierwsze opowiadanie o stworzeniu świata i człowieka ( $\mathrm{Rdz}$ $1,1-2,4 a)$.

4. Drugie opowiadanie o stworzeniu świata i człowieka $(\mathrm{Rdz}$ 2,4b-24).

5. Upadek pierwszych ludzi ( $\operatorname{Rdz} 3)$.

6. Opowiadanie o Kainie i Ablu (Rdz 4,1-16).

7. Opowiadanie o potopie $(\operatorname{Rdz} 6,5-7,17)$.

8. Opowiadanie o przekleństwie Kanaana (Rdz 9,18-27).

9. Opowiadanie o wieży Babel (Rdz 11,1-9).

10. Od „Historii początków” do „Proto-historii Izraela”.

\section{Rok 3: 1988/1989}

Parafia Opatrzności Bożej: Wielkie postacie Starego Testamentu

1. Abraham - „ojciec wierzących”.

2. Mojżesz - wybawiciel, przywódca i prawodawca.

3. Jozue - bohater czasów przełomu.

4. Samuel - ostatni sędzia Izraela.

5. Dawid i Salomon - symbole świetności Izraela.

6. Królowie Judy i Izraela - dylematy podzielonego narodu.

7. Prorok Eliasz - niezłomny mąż Boży.

8. Amos i Ozeasz - prorockie wołanie o sprawiedliwość.

9. Izajasz - „ewangelista” Starego Testamentu.

10. Jeremiasz - prorok sądu i nadziei.

11. Ezechiel - prorok czasu zagłady.

12. Aggeusz, Ezdrasz i Nehemiasz - odnowa po zagładzie.

13. Hiob - tajemnica cierpienia człowieka sprawiedliwego.

14. Machabeusze - znak sprzeciwu wobec przemocy.

15. Chrześcijański dynamizm Starego Testamentu.

Parafia Zwiastowania Pańskiego: Maryja w Nowym Testamencie

1. Zwiastowanie ( $Ł k$ 1,26-38).

2. Nawiedzenie (Łk 1,39-56).

3. Narodziny Jezusa (Mt 1,18-25; Łk 2,1-20). 
4. Ofiarowanie Jezusa w świątyni jerozolimskiej (Łk 2,22-38).

5. Cud w Kanie Galilejskiej (J 2,1-12).

6. Pod krzyżem Jezusa (J 19,25-37).

7. Maryja w Wieczerniku (Dz 1,12-26).

\section{Rok 4: 1989/1990}

\section{Parafia Opatrzności Bożej: Dekalog}

1. Dekalog w tradycji żydowskiej i chrześcijańskiej.

2. Jam jest Pan, Bóg twój...

3. Nie będziesz miał bogów cudzych przede Mną.

4. Nie będziesz Bral Imienia Pana, Boga twego, nadaremno.

5. Pamiętaj, abyś dzień święty święcił.

6. Czcij ojca swego i matkę swoją.

7. Nie zabijaj.

8. Nie cudzołóż.

9. Nie kradnij.

10. Nie mów fałszywego świadectwa przeciw bliźniemu twemu.

11. Nie pożądaj żony bliźniego twego.

12. ...Ani żadnej rzeczy, która jego jest.

13. Będziesz miłował Pana, Boga twego...

14. ...A bliźniego twego jak siebie samego.

\section{Rok 5: 1990-1991}

Parafia Opatrzności Bożej: Życie i dzieło św. Pawła Apostoła

1. Filar chrześcijaństwa.

2. Droga ku Chrystusowi.

3. Odrzucony przez Żydów, nie przyjęty przez chrześcijan.

4. Zagorzały prześladowca płomiennym głosicielem Chrystusa.

5. Żyd z pochodzenia - chrześcijanin z wyboru.

6. Pozyskiwanie pogan.

7. Konflikt między judaizmem a chrześcijaństwem.

8. Ewangelia wkracza do Europy.

9. U korzeni tożsamości chrześcijańskiej. 
10. Niestrudzony głosiciel Jezusa Chrystusa.

11. Heroiczny wyznawca Chrystusa.

12. Świadectwo prawdy i miłości.

13. U kresu drogi.

\section{Rok 6: 1991/1992}

Parafia Opatrzności Bożej: Kobiety w Starym Testamencie

1. Ewa znaczy ,życie”.

2. Sara - matka wierzących.

3. Tamar - kobieta za wszelka cenę.

4. Miriam - posłannictwo siostry.

5. Debora i Dalila - pochwała przewrotności?

6. Noemi i Rut - wzory wierności i zaradności.

7. Anna, matka Samuela - pochwała zwyczajności.

8. Batszeba - królewska wybranka.

9. Abigail - triumf kobiecej roztropności.

10. Izebel - tajemnica zła i nieprawości.

11. Judyta - siła spokoju.

12. Estera - symbol kobiecej skuteczności.

13. Matka siedmiu zamęczonych braci machabejskich.

14. Kobiety w Mateuszowej genealogii Jezusa Chrystusa (Mt 1, 1-17).

15. Kobiety w Starym Testamencie a Maryja, Matka Jezusa (I).

16. Kobiety w Starym Testamencie a Maryja, Matka Jezusa (II).

\section{Rok 7: 1992/1993}

Parafia Opatrzności Bożej: Wprowadzenie do Nowego

\section{Testamentu}

1. Zanim powstały księgi. Dobra Nowina Jezusa a Ewangelie kanoniczne.

2. Chronologia powstawania Ewangelii kanonicznych.

3. Ewangelia według św. Mateusza.

4. Ewangelia według św. Marka 
5. Ewangelia według św. Łukasza.

6. Ewangelia według św. Jana.

7. Życie Jezusa na podstawie Ewangelii kanonicznych.

8. Jezus Chrystus a współczesny Mu judaizm.

9. Narodziny Kościoła w świetle Dziejów Apostolskich.

10. Okrzepnięcie i ekspansja Kościoła.

11. Osobowość, życie i orędzie św. Pawła Apostoła.

12. Listy św. Pawła Apostoła (I).

13. Listy św. Pawła Apostoła (II).

14. Listy Deutero-Pawłowe i Listy Pasterskie.

Parafia Zwiastowania Pańskiego: Dzieje Apostolskie (Część I)

1. Dzieje Apostolskie jako kontynuacja trzeciej Ewangelii kanonicznej (Dz 1,1-4).

2. Wniebowstąpienie Jezusa (Dz 1,5-11).

3. Uzupełnienie grona Dwunastu (Dz 1,12-26).

4. Zesłanie Ducha Świętego (Dz 2,1-46).

5. Życie wspólnoty Kościoła jerozolimskiego (Dz 2,42-47).

6. Uzdrowienie chromego i oskarżycielska mowa Piotra (Dz 3).

7. Apostołowie Piotr i Jan przed Sanhedrynem (Dz 4,1-31).

8. Miłość i dobroczynność jako zasada życia wyznawców Chrystusa (Dz 4,32 - 5,16).

9. Sanhedryn przeciw apostołom i wystąpienie Gamaliela (Dz 5,17-42).

10. Ustanowienie Siedmiu i śmierć męczeńska Szczepana (Dz $6,1-7,60)$.

11. Prześladowanie Kościoła jerozolimskiego oraz działalność Filipa oraz Piotra i Jana (Dz 8).

12. Przemiana Szawła pod Damaszkiem (Dz 9,1-31). 


\section{Rok 8: $1993 / 1994^{5}$}

Parafia Zwiastowania Pańskiego: Dzieje Apostolskie (Część II)

1. Działalność Piotra i wejście pogan do Kościoła $(9,32-10,48)$.

2. Dylematy chrześcijan pochodzenia żydowskiego: Piotr wyjaśnia sprawę Korneliusza (Dz 11,1-18).

3. Początki chrześcijaństwa w Antiochii Syryjskiej (Dz 11,19-30).

4. Prześladowanie Kościoła jerozolimskiego i śmierć Heroda Agryppy (Dz 12).

5. Pierwsza wyprawa misyjna św. Pawła - cz. I (Dz 13).

6. Pierwsza wyprawa misyjna św. Pawła - cz. II (Dz 14).

7. Sobór Jerozolimski (Dz 15,1-35).

8. Druga wyprawa misyjna św. Pawła - cz. I (Dz 15,36 - 16,10).

9. Druga wyprawa misyjna św. Pawła - cz. II (Dz 16,11 - 17,15).

\section{Rok 9: 1994/1995}

Parafia Zwiastowania Pańskiego: Dzieje Apostolskie (Część III)

1. Druga wyprawa misyjna św. Pawła - cz. III (Dz 17,16 - 18,22).

2. Trzecia wyprawa misyjna św. Pawła - cz. I (Dz 18,23 - 19,40.

3. Trzecia wyprawa misyjna św. Pawła - cz. II (Dz 20).

4. Zakończenie trzeciej wyprawy misyjnej i przyjęcie przez Kościół jerozolimski (Dz 21,1-26).

5. Pojmanie Pawła na terenie świątynnym i jego przemówienie do Żydów (Dz 21,27 - 22,29).

6. Paweł przed Sanhedrynem i odesłanie go do Cezarei Nadmorskiej (Dz 22,30 - 23,35).

7. Paweł przed sądem prokuratora Feliksa (Dz 24).

8. Paweł przed trybunałem Festusa i Herodem Agryppą II (Dz 25-26).

9. Morska podróż Pawła do Rzymu (Dz 27).

10. Paweł na Malcie i w Rzymie (Dz 28).

5 Z przerwą w okresie pierwszego kwartału 1994 r., z powodu pobytu prowadzącego (z wykładami) w kilku uczelniach i instytucjach żydowskich w USA. 


\section{Parafia Opatrzności Bożej: Starożytny Izrael}

1. Okres patriarchów.

2. Niewola i wyjście z Egiptu.

3. Wejście Izraelitów do Kanaanu i okres Sędziów.

4. Okres zjednoczonej monarchii Izraela.

5. Okres podzielonej monarchii Izraela.

6. Wygnanie babilońskie i powrót do ojczyzny.

7. Okres perski i hellenistyczny (539-63 przed Chr.).

8. Okres rzymski.

\section{Rok 10: 1995/1996}

Parafia Zwiastowania Pańskiego: Kryzys w świetle Biblii

1. Kryzys zaufania Bogu (Rdz 3,1-6).

2. Kryzys sumienia - Kain i Abel (Rdz 4,1-16).

3. Kryzys tożsamości - opowiadanie o wieży Babel (Rdz 11,1-9).

4. Heroizm wiary - Abraham i Izaak (Rdz 22,1-19).

5. Mojżesz - wielkość i kryzys przywódcy.

6. Hiob - kryzys człowieka naznaczonego cierpieniem.

7. Jonasz - kryzys poczucia Bożej sprawiedliwości.

8. Jeremiasz - kryzys religii upolitycznionej.

\section{Rok 11: 1996/1997}

Parafia Zwiastowania Pańskiego: Kościoły Apostolskie

1. Jerozolima.

2. Antiochia nad Orontesem.

3. Galacja.

4. Efez.

5. Filippi.

6. Tesalonika.

7. Korynt.

8. Dziedzictwo Kościoła I wieku. 
Parafia Opatrzności Bożej: Maryja w Nowym Testamencie

1. Świadectwo św. Pawła Apostoła.

2. Świadectwo Ewangelii według św. Marka.

3. Świadectwo Ewangelii według św. Mateusza.

4. Świadectwo Ewangelii według św. Łukasza.

5. Świadectwo Ewangelii według św. Jana.

6. Świadectwo Apokalipsy.

\section{Rok 12: 1997/1998}

\section{Parafia Zwiastowania Pańskiego: Zbawienie}

1. Starotestamentowy paradygmat zbawienia: Wyjście Izraelitów $\mathrm{z}$ Egiptu.

2. Psalm 105(106) modlitwą o wybawienie.

3. Ofiara Abrahama jako model wybawienia ( $R d z 22)$.

4. Hiob - dylematy człowieka cierpiącego niewinnie.

5. Izajaszowe pieśni o Słudze Pańskim.

6. „Czyż Mesjasz nie miał tego cierpieć, aby wejść do swej chwały?" (Łk 24,26).

7. „Czyn sprawiedliwy Jednego sprowadza na wszystkich ludzi usprawiedliwienie dające życie" (Rz 5,28).

\section{Rok 13: 1998/1999}

Parafia Zwiastowania Pańskiego: Przypowieści Jezusa

1. „Uczył ich wiele w przypowieściach” (Mk 4,2).

2. Przypowieść o siewcy czy o ziarnie? (Mt 13,1-23).

3. Przypowieść o miłosiernym Samarytaninie ( Łk 10,30-37).

4. Przypowieści o miłosierdziu (Łk 15).

5. Przypowieść o potrzebie ustawicznej czujności (Mt 24,45-51).

6. Przypowieści o odrzuceniu Jezusa (Mt 21,33 - 22,14).

7. Ostatnia przypowieść Jezusa (Mt 25,14-30).

8. „Przypominam, bracia, Ewangelię, którą wam głosiłem” $(1$ Kor 15,1$)$. 


\section{Rok 14: 1999/2000}

Parafia Zwiastowania Pańskiego: Czytamy Stary Testament

1. Jak czytać Stary Testament?

2. Księga Rodzaju.

3. Księga Wyjścia.

4. Ksiga Kapłańska.

5. Księga Liczb.

6. Księga Powtórzonego Prawa.

7. Księga Jozuego.

8. Księga Sędziów.

9. Pierwsza i Druga Księga Samuela.

\section{Rok 15: 2000/2001}

Parafia Zwiastowania Pańskiego: Siedem Kościołów Apokalipsy

1. Listy do siedmiu Kościołów Apokalipsy (Ap 2-3).

2. List do Kościoła w Efezie (Ap 2,1-7).

3. List do Kościoła w Smyrnie (Ap 2,8-11).

4. List do Kościoła w Pergamonie (Ap 2,12-17).

5. List do Kościoła w Tiatyrze (Ap 2,18-29).

6. List do Kościoła w Sardes (Ap 3,1-6).

7. List do Kościoła w Filadelfii (Ap 3,7-13).

8. List do Kościoła w Laodycei (Ap 3,14-22).

\section{Rok 16: 2001/2002}

Parafia Zwiastowania Pańskiego: Przekroczyć próg nadziei

1. Papież: wyzwanie i tajemnica.

2. Ale dlaczego Bóg się ukrywa?

3. Zbawienie w centrum dziejów ludzkości.

4. Bóg jest Miłością, ale dlaczego tyle zła?

5. Dlaczego tyle religii?

6. Wyzwania nowej ewangelizacji.

7. W poszukiwaniu utraconej jedności. 
8. „Bóg bogaty w miłosierdzie”. W oczekiwaniu na pielgrzymkę Jana Pawła II do ojczyzny.

\section{Rok 17: 2002/2003}

Parafia Zwiastowania Pańskiego: Czytamy Nowy Testament

1. Od Ewangelii Jezusa do Ewangelii Nowego Testamentu.

2. Ewangelia według św. Marka.

3. Ewangelia według św. Mateusza.

4. Ewangelia według św. Łukasza.

5. Dzieje Apostolskie.

6. Ewangelia według św. Jana.

7. Pierwszy i Drugi List św. Pawła do Koryntian.

8. List św. Pawła do Rzymian.

9. List do Hebrajczyków.

\section{Rok 18: 2003/2004}

Parafia Zwiastowania Pańskiego: Apostołowie Jezusa Chrystusa

1. Tożsamość i zadania apostoła za życia Jezusa i po Jego zmartwychwstaniu.

2. Święty Piotr (cz. I).

3. Święty Piotr (cz. II).

4. Święty Jan.

5. Święty Filip i św. Bartłomiej.

6. Judasz.

7. Pedagogia apostolska na przykładzie Pierwszego Listu św. Pawła do Tymoteusza.

8. Współczesny apostoł - refleksja na kanwie książki Jana Pawła II Wstańcie, chodźmy. 
Rok 19: 2004/2005

Parafia Zwiastowania Pańskiego: Wybrane perykopy Starego Testamentu

1. Księga Hioba (cz. I).

2. Księga Hioba (cz. II).

3. Księga Rodzaju 12,1-3 i 22,1-3.

4. Księga Wyjścia 3,1-14.

5. Pieśń nad pieśniami.

6. Pieśni o Słudze Pańskim. ${ }^{6}$

\section{Rok 20: 2005/2006}

Parafia Zwiastowania Pańskiego: Bohaterowie wiary Nowego Testamentu

1. Maryja (cz. I).

2. Maryja (cz. II).

3. Mędrcy ze Wschodu (Mt 2,1-12).

4. Nikodem (J 3,1-21).

5. Piłat (J 18,28 - 19,16).

6. Wskrzeszenie Łazarza (J 11,1-44).

7. Samarytanka (J 4,1-42).

\section{Rok 21: 2006/2007}

Parafia Zwiastowania Pańskiego: Eklezjologia Nowego

Testamentu

1. Korzenie eklezjologii biblijnej: Pierwszy List św. Pawła do Tesaloniczan.

2. Charyzmat osoby a charyzmat urzędu.

3. Eschatologiczny wymiar Kościoła.

6 Cykl poświęcony egzegezie wybranych perykop Starego Testamentu zamknęły trzy konferencje bilansujące pontyfikat Jana Pawła II (16 X 1978 - 2 IV 2005) oraz prezentujące osobę i dzieło kard. Józefa Ratzingera/Benedykta XVI. 
4. Przymioty biskupa w świetle nauczania św. Pawła.

5. Kościół wobec przeciwności i trudności.

6. Natura i posłannictwo Kościoła w świetle zesłania Ducha Świętego (Dz 2).

7. Kościół jako miejsce interpretacji Pisma Świętego.

\section{Rok 22: 2007/2008}

Parafia Zwiastowania Pańskiego: Spotkać Jezusa dzisiajczytanie Ewangelii z Benedyktem XVI

1. Chrzest Jezusa.

2. Kuszenie Jezusa.

3. Ewangelia o królestwie Bożym.

4. Osiem Błogosławieństw.

5. Modlitwa Pańska.

6. „I nie wódź nas na pokuszenie”.

7. Uczniowie Jezusa.

8. Mowa eucharystyczna Jezusa.

9. Słowo Boże w życiu i misji Kościoła.

\section{Rok 23: 2008/2009}

Parafia Zwiastowania Pańskiego: Na drogach św. Pawła

1. Tożsamość i formacja Pawła.

2. Przemiana pod Damaszkiem.

3. "Za łaską Boga jestem tym, kim jestem” (1Kor 15,10).

4. „Wyznaczcie mi już Barnabę i Szawła do dzieła, do którego ich powołałem (Dz 13,2).

5. „Zobaczmy, jak się mają bracia we wszystkich miastach, w których głosiliśmy słowo Pańskie" (Dz 15,36).

6. „Przepraw się do Macedonii i pomóż nam” (Dz 16,9).

7. „My głosimy Chrystusa ukrzyżowanego, który jest zgorszeniem dla Żydów, a głupstwem dla pogan" (1Kor 1,23).

8. „Izraelici! Na pomoc! To człowiek, który wszędzie naucza wszystkich przeciwko narodowi i Prawu" (Dz 21,28). 
9. „Krew moja już ma być wylana na ofiarę, a chwila mojej rozłąki nadeszła" $(2 \mathrm{Tm} 2,6)$.

\section{Rok 24: 2009/2010}

Parafia Zwiastowania Pańskiego: Biblijne obrazy powołania

1. „Wyjdź ty z twojej ziemi...” (Rdz 12,1) - Abraham.

2. „Weź twego syna jedynego, którego miłujesz...” (Rdz 22,2) - Abraham.

3. „Idź przeto teraz, oto posyłam cię do faraona, i wyprowadź mój lud, Izraelitów, z Egiptu" (Wj 3,10) - Mojżesz.

4. "Człowiek widzi to, co dostępne dla oczu, a Pan widzi serce” (1Sm 16,7) - Dawid.

5. „Oto ja, poślij mnie!” (Iz 6,8) - Izajasz.

6. „Nie lękaj się ich, bo jestem z tobą, by cię chronić” (Jr $1,8)$ - Jeremiasz.

7. „Nie jestem ja prorokiem ani nie jestem uczniem proroków” (Am 7,14) - Amos.

8. „Przypatrzcie się, bracia, powołaniu waszemu” (1Kor 1,26).

\section{Rok 25: 2010/2011}

Parafia Zwiastowania Pańskiego: Bóg wobec człowiekaczlowiek wobec Boga

1. Stworzenie i upadek ( $\operatorname{Rdz} 2-3)$.

2. Kain i Abel (Rdz 4).

3. Noemi i Rut (Rt).

4. Mędrcy ze Wschodu (Mt 2,1-12) - paradygmat wiary pogan.

5. Opowiadanie o Balaamie (Lb 22-24).

6. Krzyż na Golgocie - Krzyż polski.

7. Jan Paweł II ze Zbawicielem z krzyżem swoim. ${ }^{7}$

8. Bóg objawiony w Jezusie Chrystusie - Bóg obecny w Kościele.

7 Dwugłos z Adamem Bujakiem podczas promocji albumu Krzyż polski, Biały Kruk, Kraków 2011. 
9. „Wielokrotnie i na różne sposoby przemawiał niegdyś Bóg do ojców przez proroków" (Hbr 1,1).

\section{Rok 26: 2011/2012}

Parafia Zwiastowania Pańskiego: Biblia Księga życia

1. Geneza i natura Biblii Hebrajskiej.

2. Bóg jako Autor Pisma Świętego.

3. Od pierwszych zapisów świętej Tradycji Izraela do pierwszej publicznej lektury Pisma (Ezdrasz).

4. Od oryginału do przekładów: Biblia Hebrajska a Biblia Aramejska.

5. „Bóg przemówił po grecku”: Septuaginta.

6. Psalmy - księga modlitwy ludu Bożego.

7. Od Zwiastowania przez Krzyż do Zmartwychwstania.

8. Nowy Testament jako świadectwo historii i wiary.

\section{Rok 27: 2012/2013}

Parafia Zwiastowania Pańskiego: Biblijni bohaterowie wiary

1. Adam i Ewa, czyli gdybyśmy wiedzieli, że Bóg istnieje.

2. U źródeł zawierzenia Bogu - Abraham (Rdz 11,27 - 12,6).

3. Dzieciństwo Jezusa oczami Benedykta XVI (cz. I).

4. Dzieciństwo Jezusa oczami Benedykta XVI (cz. II).

5. Refleksje po rezygnacji Benedykta XVI z urzędu biskupa Rzymu. $^{8}$

6. Mowa eucharystyczna Jezusa w Kafarnaum (J 6).

7. Psalmiści - ludzie modlitwy.

8. Modlitwy na kartach Nowego Testamentu.

8 Konferencja wygłoszona wieczorem 11 II 2005 r., czyli kilka godzin po rezygnacji papieża Benedykta XVI z urzędu biskupa Rzymu. 


\section{Rok 28: 2013/2014}

Parafia Zwiastowania Pańskiego: Cztery Ewangelie kanoniczne

1. Cztery Ewangelie kanoniczne jako portrety Jezusa Chrystusa.

2. Teologia Ewangelii według św. Mateusza.

3. Ewangelia według św. Mateusza: pytania i odpowiedzi.

4. Teologia Ewangelii według św. Marka.

5. Ewangelia według św. Marka: pytania i odpowiedzi.

6. Teologia Ewangelii według św. Łukasza.

7. Ewangelia według św. Łukasza: pytania i odpowiedzi.

8. Teologia Ewangelii według św. Jana.

9. Ewangelia według św. Jana: pytania i odpowiedzi.

\section{Rok 29: 2014/2015}

\section{Parafia Zwiastowania Pańskiego: Chrystologia Starego}

\section{Testamentu}

1. Zasadność i natura chrystologii Starego Testamentu.

2. „Stwórzmy człowieka na Nasz obraz” (Rdz 1,26-27).

3. „Tres vidit, sed Unum adoravit”: Bóg w gościnie u Abrahama ( $\mathrm{Rdz} 18)$.

4. Ofiarowanie Izaaka ( $\mathrm{Rdz} 22)$.

5. Znak miedzianego węża (Lb 21,4-9): starotestamentowa zapowiedź krzyża.

6. Psalm 22(21): modlitwa konającego Mesjasza.

7. Wizja ożywienia wyschniętych kości (Ez 37,1-2).

8. Księga Hioba - sens cierpienia niewinnych.

\section{Kilka uwag i konkluzji}

Na kanwie trwającej tak długo i systematycznie realizowanej inicjatywy popularyzującej Biblię i wiedzę biblijną, na która złożyło się łącznie 327 konferencji biblijnych, nasuwa się wiele spostrzeżeń i wniosków. Oto niektóre, najpierw o charakterze praktycznym, 
zapewne przydatne do planowania i podejmowania analogicznych przedsięwzięć:

Po p i e rws ze, wszystkie konferencje były wygłaszane wieczorem, wkrótce po ostatniej mszy św., co umożliwiało łączenie uczestnictwa w nich z Eucharystią. Gdy tradycja konferencji się utrwaliła, zwiększyła się też wyraźnie liczba wiernych podczas mszy św. Znaczy to, że uczestnicy konferencji to osoby dojrzałe w wierze i prowadzące życie sakramentalne. Każda konferencja trwała około jedną godzinę zegarową, na ogół nieco dłużej, a nigdy krócej.

Po d rugi e, miejscem konferencji był kościół dolny w parafii Opatrzności Bożej oraz najpierw prowizoryczna kaplica, a później sala katechetyczna i następnie nowo oddany do użytku kościół dolny w parafii Zwiastowania Pańskiego. Nie wymagało to specjalnych przygotowań ani nakładu kosztów, z wyjątkiem sprzętu nagłaśniającego i zapewnienia większości uczestnikom miejsc siedzących. Nagrywania poszczególnych konferencji podjęło się kilkoro uczestników, którzy służyli własnym sprzętem i skutecznie ze sobą współpracowali.

Po tr z e ci e, konferencje nie były reklamowane ani ogłaszane w innych kościołach i parafiach niż te, w których je wygłaszano. Wiadomości podawane w niedzielnych ogłoszeniach parafialnych, rozchodziły się telefonicznie i dzięki rekomendacjom, przyciągając wciąż nowych uczestników. Na zakończenie każdej konferencji podawano datę następnej, planowanej za dwa tygodnie albo za miesiąc. W ciągu całego okresu tylko w absolutnie wyjątkowych sytuacjach należało dokonać koniecznej korekty.

Po c z w a r t e, trzy dekady istnienia tego przedsięwzięcia spowodowały, że uczestniczą w nim w gruncie rzeczy dwa kolejne pokolenia wiernych. Nie zabrakło przypadków kontynuacji udziału ,z rodziców na dzieci". To samo odnosi się do materiałów konferencji, które trafiając do domów, krążyły w rodzinach i wśród znajomych.

Po p i ą t e, każda konferencja została poprzedzona wspólnym odmówieniem Modlitwy Pańskiej i wybranego wezwania z Litanii Loretańskiej, a zakończona modlitwą maryjną „Pod Twoją obronę”. Dzięki temu nie mają one wyłącznie charakteru akademickiego, 
lecz służą budowaniu i wzmacnianiu wiary oraz tożsamości chrześcijańskiej.

Po s z ó st e, na pierwszym dorocznym spotkaniu, w październiku, uczestnicy otrzymywali zapowiedź i uzasadnienie tytułu rozpoczynającego się cyklu oraz byli wprowadzani w jego treść. Kolejne konferencje stanowiły więc ogniwa starannie przemyślanej i zaplanowanej całości. Bardzo rzadko, gdy wydarzyło się coś ważnego w życiu Kościoła, konferencja odchodziła od tytułowego tematu i dlatego nie została uwzględniona w powyższym wykazie.

Po s i ó d m e, w kontekście wielu konferencji istniała możliwość zaopatrzenia się w egzemplarz Biblii oraz nabycia wskazanych publikacji biblijnych.

Co się tyczy merytorycznej strony konferencji, też nasuwa się kilka istotnych obserwacji:

Po p i e r w s z e, przedmiotem refleksji były zagadnienia ogólne, z zakresu wprowadzenia do Pisma Świętego, a także wybrana szczegółowa problematyka Starego i Nowego Testamentu - o profilu historycznym, archeologicznym, geograficznym i topograficznym oraz egzegetycznym i teologicznym.

Po d r u g i e, częściej podejmowano problematykę nowotestamentową, zwłaszcza dotyczącą osoby i posłannictwa Jezusa Chrystusa oraz treści czterech Ewangelii kanonicznych, wiele miejsca poświęcono również początkom Kościoła, przede wszystkim przedstawionym w Dziejach Apostolskich, a także życiu i działalności św. Pawła. Mimo to często była też podejmowana problematyka starotestamentowa.

Po tr ze c i e, przedmiotem konferencji były zarówno wybrane postacie biblijne, a wśród nich szczególnie Jezus Chrystusa i Maryja, jak też rozmaite wydarzenia $\mathrm{z}$ historii zbawienia. Wiele konferencji miało profil egzegetyczny, czyli podejmowana refleksja bazowała na wnikliwej lekturze wybranych perykop biblijnych. Często były odczytywane w języku oryginału, to jest hebrajskim, aramejskim i greckim, dając słuchaczom możliwość lepszej orientacji w dziedzinie specyfiki i natury translatoryki biblijnej. 
Po c zwarte, pewne tematy i wątki przewijały się wielokrotnie i wracały $w$ kolejnych latach, nie tyle przypominane, ile raczej „dopowiadane" i ukazywane z innej perspektywy, co sprzyjało ich głębszemu i pełniejszemu zrozumieniu i przyswojeniu. Miało to związek również z rytmem roku liturgicznego, zwłaszcza z okresem Wielkiego Postu, usposabiającym do rozważania męki i śmierci Jezusa Chrystusa.

Po p i ą te, dobór dorocznej problematyki uwzględniał z jednej strony wcześniej podjęte zagadnienia, zaś z drugiej bywał podyktowany doraźnymi okolicznościami i uwarunkowaniami, np. przygotowania do Wielkiego Jubileuszu Roku 2000, Rok Św. Pawła czy ukazanie się książki Przekroczyć próg nadziei Jana Pawła II oraz Jezus z Nazaretu Józefa Ratzingera/Benedykta XVI.

Po s z ó s te, kluczowe znaczenie miało podejmowanie istotnych zagadnień teologicznych, zwłaszcza z zakresu chrystologii, soteriologii, eklezjologii i mariologii, zawsze w nawiązaniu do aktualnych wyzwań i uwarunkowań dochodzących do głosu w Kościele katolickim.

Po s i ó d m e, część dorocznych cykli miała charakter interaktywny, czyli istniała możliwość zadawania pytań, a w jednym roku (2013/2014) konferencje oraz sesje pytania-odpowiedzi odbywały się naprzemiennie.

Po ó s m e, uczestnicy byli nieustannie zachęcani do osobistej lektury Biblii, ze wskazaniem konkretnych ksiąg czy perykop. Nie zabrakło świadectw osób, które przeczytały całe Pismo Święte według udzielonej im rady: jeden rozdział dziennie.

Najważniejsze jest to, że uczestnikom wieloletnich konferencji należy się ogromne uznanie i szczery podziw. Przybywali na spotkania w trudnej porze jesiennej i zimowej oraz wiosennej, regularnie i punktualnie, robiąc notatki i zapamiętując rozważane treści. Ich obecność, zasłuchanie i wdzięczność stanowiły najskuteczniejszą motywację do kontynuowania tego dzieła i największą nagrodę za jego realizację. 